\title{
SEA MUSLIM MINORITAS: SOUTH THAILAND/PATTANI, SOUTH PHILIPPINES/MINDANAU AND THAILAND
}

\author{
Oleh: \\ Ali Geno Berutu \\ ali_geno@ymail.com
}

\section{A. Pendahuluan}

Salah satu rintangan yang paling serius dalam mengembangkan pemahaman tentang Islam di Asia Tenggara adalah adanya suatu fakta bahwa topik kajian tentang Islam Asia Tenggara telah lama sekali terpinggirkan dalam lapangan studi Islam. Hal tersebut disebabkan dalam studi Islam para sarjanan Barat dan Timur Tengah memiliki kecenderungan yang menempatkan Asia Tenggara di pinggiran dalam arus intelektual di dunia Islam. Berbagai tulisan tentang sejarah dan peradaban Islam tapi Islam di Asia Tenggara hanya dibahas sekilas atau bahkan tidak sama sekali. Padahal kenyataannya, Asia Tenggara memiliki hampir 200 juta muslim, para pengamat bahkan sebagian intelektual belum terbiasa mengidentifikasikan Islam Asia Tenggara dengan Islam di Timur Tengah dan menganggap Asia Tenggara secara intelektual dan institusional sebagai pengembangan Islam dari Timur Tengah. ${ }^{1}$

Masyarakat Asia Tenggara dikenal sebagai muslim Melayu. Azyumardi Azra berpendapat bahwa Islam Asia Tenggara dikategorikan sebagai wilayah kebudayaan yang cukup berpengaruh dari tujuh wilayah kebudayaan Islam yang ada di dunia. Perkembangan Islam di Aasia Tennggara mengalami pasang surut yang disebabkan oleh beberpa faktor seperti kondisi pendidikan, sosial dan politik. Pertumbuhan dsetiap negara tidaklah sama, ada kawasan yang mengalami pertumbuhan yang sangat pesat bahkan Islam menjadi bagian dari negara tersebut dalam berbagai aspek kehidupan.

\section{Muslim Pattani, Thailand}

Kedatangan Ilsam ke Asia Tenggara pada umumnya melaui proses perdagangan. Hal ini sangatlah memungkinkan bila dilihat dari letak geografis

${ }^{1}$ Rina Rehayati, "Minoritas Muslim: Belajar dari Kasus Minoritas Muslim di Filipina”, Jurnal Ushuluddin Vol. XVII No. 2, Juli 2011, 225. 
negara-negara di Asia Tenggara yang berupa kemaritiman dan pada saat itu sekali gus sebagai jalur perdagangan yang sibuk pada masanya. Teori-teori tentang masuknya Islam ke Asia Tenggara meliputi teori Arab, teori India, Teori Persia dan teori Cina. Kedatangan Islam di Thailand yang dibawa oleh pedangan Arab diperkirakan terjadi pada abad ke $10 \mathrm{M}$. Ajaran Islam diterima dengan baik oleh masyarakat Thailand khususnya Thailand bagian selatan. ${ }^{2}$

Penyebaran Islam dilakukan para guru sufi pengembara dan pedagang yang berasal dari wilayah Arab dan pesisir India. Salah satu bukti yang menguatkan pendapat ini adalah ditemukannya batu nisan bertuliskan Arab dekat Kampung Teluk Cik Munah, pekan Pahang yang bertarikh 1028 M. dalam catatan Emmanuel Gedinho d'Eredia, seorang penulis Portugis pada awal abad ke-17, disebutkan bahwa Islam terlebih dahulu datang ke daerah Pattani dan Pahang, kemudian masuk ke Malaka. Sumber lain, seperti tulisan A. Bangnara, seorang pakar sejarah bangsa Pattani di Thailand, menyebutkan bahwa Islam pada awalnya tersebar di kalangan rakyat biasa. Meskipun demikian, ada pula pendapat yang mengatakan bahwa Islam pada awalnya diterima oleh kalanga penguasa (elite), baru kemudian menyebar ke kalangan rakyat. $^{3}$

Pendapat di atas bertentangan dengan pendapat yang dikemukakan Azyumardi Azra dalam Ensiklopedi Tematis Dunia Islam Asia Tenggara, bahwa Islam masuk di Thailand diperkirakan pada Abad ke-10 atau ke- $11^{4}$ di Thailand selatan atau tepatnya di daerah Pattani. Islam masuk ke daerah kerajaan Pattani melalui pedagang-pedagang muslim dari Arab dan India ${ }^{5}$ karena daerah Pattani merupakan daerah yang maju dan strategis untuk disinggahi. ${ }^{6}$ Islam di Pattani disebut sebagai khek Islam atau orang muslim sebelum kerajaan Siam (Thailand) dibentuk. Karena pada awalnya, Pattani merupakan daerah yang terpisah dari Siam (saat ini Thailand), Muslims have been in Thailand since before the formation of the Thai kingdoms in the ninth century. ${ }^{7}$

Thailand yang merupakan bagian dari Asia Tenggara merupakan negara yang dimana Islam adalah sebagai agama minoritas yang terletak di Thailand bagian Selatan. Perbedaan agama dan suku masyarakat Thailand khususnya masyarakat Thailand Selatan seringkali mengalami diskriminasi dari pemerintahan Thailand.

${ }^{2}$ Moh Mizan Aslam, Penyelesaian Konflik Thailand Selatan Menggunakan Model Gagasan Gagasan 1 Malaisya, Journal of Human Development and Comunications, Vol. 1 2012, 139.

${ }^{3}$ Taufik Abdullah, [et.al.], Ensiklopedi Tematis Dunia Islam, (Jakarta: Ichtiar Baru Van Hoeve), 466.

4 Azyumardi Azra, Ensiklopedi Tematis Dunia Islam, Asia Tenggara, No. 5, (Jakarta: PT Ichtiar Baru Van Hoeve, 2002), 466.

5 Siti Maryam, Sejarah Peradaban Islam Dari Masa Klasik Hingga Modern, (Yogyakarta: Lesfi, 2004), 332.

6 Thanet Aphornsuvan, History and Politics of The Muslim in Thailand, (Thammasat University: 2003), 3.

${ }^{7}$ Thanet Aphornsuvan, History and Politics of The Muslim in Thailand..., 7. 
Hal tersebut telah menyebabkan banyak pertikaian diantara keduanya. Pada kisaran tahun 2004-2007 lebih dari 2000 orang telah meninggal dalam pertikaian yang terjadi tersebut. Mulai dari penembakan di masjid Kru Se hingga peristiwa Takbai. Berbagai pertikaian berdarah tersebut merupakan salah satu hal yang timbul dari berbagai macam problem yang dihadapi masyarakat muslim Thailand.

Wilayah perbatasan (sempadan) selatan Thailand yang dikenal dengan nama Changwad Chaiden Pak Thai banyak dihuni oleh komunitas Muslim keturunan Melayu. Wilayah ini terdiri dari empat provinsi; Yala, Narathiwat, Patani dan Satun dengan agama Islam yang mendominasi populasi di wilayah tersebut. Di keempat provinsi ini ikatan sejarah ke-Melayu-an memiliki karakter cukup kuat dibandingkan dengan bangsa Thai. Kenyataan ini membuat komunitas Muslim di Thailand Selatan memiliki perbedaan agama, adat istiadat, bahasa dan tata cara kehidupan yang berbeda dengan bangsa Thai umumnya. Identitas yang dimiliki oleh masyarakat Muslim Thailand Selatan memperlihatkan entitas kolektif orang-orang Melayu di empat provinsi ("the four provinces") sebagai suatu manifestasi dari identitas etnik Melayu yang berada di Thailand. ${ }^{8}$ Masyarakat dan pemerintah Thailand lantas menyebut komunitas di selatan ini dengan istilah "Thai Muslim".

Thai Muslim atau yang lebih dikenal dengan Muslim Patani secara umum lebih banyak dideskripsikan sebagai komunitas Muslim yang secara sporadis sering melakukan gerakan perlawanan bersenjata serta menentang sikap dan perlakuan diskriminatif pemerintah Thailand. Pemberitaan media juga turut menggambarkan bahwa kekerasan kerap berlangsung dan diwarnai dengan aksi balas dendam yang menimbulkan banyak korban, baik dari komunitas Muslim maupun dari masyarakat Thailand yang beragama Budha. Selain itu, gambaran kaum minoritas Muslim di Thailand adalah kaum tertindas, terutama disebabkan oleh sikap pemerintah yang mau menang sendiri dan tidak bersedia untuk memahami aspirasi yang berkembang dalam masyarakat Islam Patani. ${ }^{9}$

Pada medio tahun 2004 sampai 2007 lebih dari 2000 orang telah meninggal dalam pertikaian yang terjadi di Thailand Selatan. Mulai dari penembakan di masjid Kru hingga peristiwa Takbai. Berbagai pertikaian berdarah tersebut merupakan salah satu hal yang timbul dari berbagai macam problem yang dihadapi masyarakat muslim Thailand. Pemerintah Thailand seringkali menyebut orang muslim Pattani sebagai "Islam Thai" sebuah istilah yang sebenarnya kurang tepat karena mereka lebih dekat dengan etnis dan budaya Melayu daripada Thailand. Mereka adalah kelompok etnik yang terpisah dari induknya dunia Melayu Muslim Asia Tenggara. ${ }^{10}$

Muslim di Thailand sekitar $15 \%$ sedangkan penganut Budha berkisar $80 \%$. Mayoritas Muslim tinggal di Selatan Thailand, sekitar 1,5 juta jiwa, atau $80 \%$ dari

8 Paulus Rudolf Yuniarto, "Minoritas Muslim Thailand Asimilasi, Perlawanan Budaya Dan Akar Gerakan Separatisme", Jurnal Masyarakat Dan Budaya, Volume 7 No.1 Tahun 2005, 90-91.

${ }^{9}$ Paulus Rudolf Yuniarto, "Minoritas Muslim Thailand Asimilasi ..., 91.

${ }^{10}$ Surin Pitsuwan, Islam di Muangthai Nasionalisme Melayu Masyarakat Patan, (Jakarta: LP3ES, 1989), 3. 
total penduduk, khususnya di Patani, Yala dan Narathiwat, tiga provinsi yang sangat mewarnai dinamika di Thailand Selatan. Tradisi muslim di wilayah ini mengakar sejak kerajaan Sri Wijaya yang menguasai wilayah Asia Tenggara, termasuk Thailand Selatan.

Thailand Selatan terdiri dari lima provinsi: Pattani, Yala, Narathiwat, Satun dan Songkhla, dengan total penduduk 6.326.732 (Kantor Statistik Nasional, Thailand, 2002). Mayoritas penduduk muslim terdapat di empat provinsi: Pattani, Yala, Narathiwat dan Satun, yaitu sekitar 71\% diperkotaan, dan $86 \%$ di pedesaan (YCCI, 2006: 34), sedangkan di Songkhla, Muslim sekitar $19 \%$, minoritas, dan $76.6 \%$ Buddha. Sementara mayoritas penduduk yang berbahasa Melayu, rata-rata $70 \%$ berada di tiga provinsi: Pattani, Yala dan Narathiwat, sementara penduduk berbahasa China, ada di tiga provinsi: Narathiwat, $0.3 \%$, Pattani, $1.0 \%$, dan Yala, $3.0 \%$ (Sensus Penduduk, Thailand, 2000). ${ }^{11}$

\section{Perjuanag Muslim Thailand Selatan dalam Melawan Ketikadilan Pemerintah}

Dinamika politik, keamanan dan sosial telah menumbuhkan gerakan di tingkat lokal di Thailand Selatan, khususnya di tiga provinsi: Narathiwat, Yala dan Pattani. Diantaranya adalah Barisan Revolusi Nasional (BRN), Pattani United Liberation Organisation (PULO), dan Gerakan Mujahidin Islam Pattani (GMIP). BRN menuntut pemisahan diri dengan menggunakan ideologi sosialis, dan bekerjasama dengan Partai Komunis Melayu di perbatasan pada tahun 1950an. Sementara PULO adalah gerakan separatis yang menuntut wilayah Patani -sebutan untuk tiga provinsi Narathiwat, Yala dan Pattani- sebagai daerah yang merdeka.

Tuntutan awal mereka adalah berpisah dari Thailand ${ }^{12}$ dan memilih untuk bergabung dengan Malaysia. Wakil Presiden PULO dipengasingan Haji Lukman Bin Lima, mengumandangkan "Jihad" sebagai gerakan melawan "Pemerintah Kafir Thai-Buddhis", yang ditujukan untuk mengakhiri dominasi mereka atas wilayah Melayu Islam Patani. GMIP memiliki identitas ke-islaman yang lebih kuat. Meskipun semua menuntut kemerdekaan, tetapi masing-masing memiliki karakter dan identitas gerakan sendiri. Pada beberapa tahun setelah didirikan, mereka mencoba disatukan dalam satu atap dengan menggunakan istilah melayu yaitu "bersatu". Tetapi karena sejak awal didirikan dengan ideologi yang berbeda, "bersatu” juga tidak efektif untuk menyatukan seluruh gerakan.

Meskipun tidak memiliki peran untuk mengontrol anggota PULO yang masih aktif, generasi tua PULO di Eropa menawarkan upaya negosiasi dengan pemerintah Thailand. Pada Juli 2002, Thaksin memerintah keponakannya Jenderal

${ }^{11}$ Brown, David Brown, The State and Ethnic Politics in South-East Asia, (London dan New York: Routledge, 2004), 48.

12 Saiful Mujani (edt), Pembangunan dan Kebangkitan Islam di Asia Tenggara, (Jakarta: LP3ES, 1993), 54. 
Chaisit Shinawatra untuk bernegosiasi dengan elemen PULO dan BRN. Ini menunjukkan bahwa kelompok separatis masih perlu diperhitungkan kekuatannya. Meskipun para komandan "bersatu” telah ditangkap atau terbunuh, sisa gerilyawan masih melakukan beberapa kekerasan. ${ }^{13}$

Secara prinsip pada tahun 2006, hampir seluruh faksi yang memberontak menandatangani perjanjian nota rekonsiliasi: "Joint Peace and Development Plan for South Thailand” (Perdamaian Bersama dan Rencana Pembangunan Thailand Selatan). Diantara mereka adalah PULO, Barisan Revolusi Nasional Konggres (BRN-C), Bersatu, Gerakan Mujahidin Islam Pattani (GMIP), dan Barisan Pembebasan Islam Pattani. Tetapi karena pemimpin GMIP yang ditangkap di Malaysia, beberapa anggota masih melakukan operasi di Selatan, demikian juga BRN-C masih melakukan serangan. ${ }^{14}$

Di tingkat grassroot, jurnalis muslim melakukan advokasi yang didukung oleh LSM independen di Thailand. Universitas Prince Sonkla di Pattani juga aktif mendukung upaya perdamaian. The Asian Muslim Action Network (AMAN) juga melakukan upaya rehabilitasi bagi masyarakat korban kekerasan dan generasi muda yang mengalami imbas negatif dari konflik. Disamping itu Majelis Ulama, Pondok Pesantren dan Madrasah secara prinsip mendukung upaya rekonsiliasi dan perdamaian. Keinginan kuat mereka tidak diimbangi dengan kebijakan pemerintah atas keamanan dan lemahnya dukungan atas kemajuan pendidikan secara luas dan kesempatan kerja di Thailand Selatan.

Hingga saat ini masyarakat Muslim Pattani hidup dalam ketakutan, mirip suasana Aceh pada masa Daerah Operasi Militer/DOM. Kehidupan mereka diawasi secara ketat oleh militer Thailand. Kekejaman tentara Thailand itu tercatat dalam peristiwa pembunuhan massal di Masjid Kerisek di Pattani dan Tak Bai di wilayah Menara (2004) dan di Masjid Al-Furqan di wilayah Menara (2009). Hampir 100 orang meninggal dunia di tangan tentara saat itu. Itu belum termasuk pemerkosaan yang dialami para gadis Muslimah dan perusakan generasi muda Muslim dengan narkoba.

\section{PERMASALAHAN DI THAILAND SELATAN}

Konflik yang terjadi di Thailand Selatan adalah konflik yang terjadi karena pertarungan antara Muslim melayu dengan Budhis Thai. Hal ini tidak lepas dari fakta yang ada. Bahwasanya sebagian besar masyarakat di daerah Thailand Selatan khususnya di daerah Pattani adalah orang melayu muslim. Hal ini telah melahirkan berbagai macam problem yang harus diatasi oleh umat muslim Thailand.

${ }^{13}$ Liow, Joseph Chinyong, Muslim Resistence in Southern Thailand and Southern Philippines: Religion, ideology and politics, (Washington: East-West Center, 2006), 35.

${ }^{14}$ Riddell, Peter, Islam And The Malay-Indonesian World, (Singapore: Horizon Book, 2001), 200. 


\section{a. Politik, Keamanan dan Sosial}

Dinamika politik, keamanan dan sosial telah menumbuhkan gerakan di tingkat lokal di Thailand Selatan, khususnya di tiga provinsi: Narathiwat, Yala dan Pattani. Diantaranya adalah Barisan Revolusi Nasional (BRN), Pattani United Liberation Organisation (PULO), dan Gerakan Mujahidin Islam Pattani (GMIP). BRN menuntut pemisahan diri dengan menggunakan ideologi sosialis, dan bekerjasama dengan Partai Komunis Melayu di perbatasan pada tahun 1950an. Sementara PULO adalah gerakan separatis yang menuntut wilayah Patani -sebutan untuk tiga provinsi Narathiwat, Yala dan Pattani- sebagai daerah yang merdeka. Mereka pada tuntutan awal memilih untuk bergabung dengan Malaysia. Wakil Presiden PULO dipengasingan, Haji Lukman Bin Lima, mengumandangkan 'Jihad' sebagai gerakan melawan 'Pemerintah Kafir Thai-Buddhis', yang ditujukan untuk mengakhiri dominasi mereka atas wilayah Melayu Islam Patani. GMIP memiliki identitas keislaman yang lebih kuat. Meskipun semua menuntut kemerdekaan, tetapi masing- masing memiliki karakter dan identitas gerakan sendiri. Pada beberapa tahun setelah didirikan, mereka mencoba disatukan dalam satu atap, dengan menggunakan istilah melayu yaitu Bersatu. Tetapi karena sejak awal didirikan dengan ideologi yang berbeda, Bersatu juga tidak efektif untuk menyatukan seluruh gerakan.

Meskipun tidak memiliki peran untuk mengontrol anggota PULO yang masih aktif, generasi tua PULO di Eropa menawarkan upaya negosiasi dengan pemerintah Thailand. Pada Juli 2002, Thaksin memerintah keponakannya Jenderal Chaisit Shinawatra untuk bernegosiasi dengan elemen PULO dan BRN. Ini menunjukkan bahwa kelompok separatis masih perlu diperhitungkan kekuatannya. Meskipun para komandan Bersatu telah ditangkap atau terbunuh, sisa gerilyawan masih melakukan beberapa kekerasan. ${ }^{15}$

Secara prinsip pada tahun 2006, hampir seluruh faksi yang memberontak menandatangani perjanjian nota rekonsiliasi: 'Joint Peace and Development Plan for South Thailand (Perdamaian Bersama dan Rencana Pembangunan Thailand Selatan). Diantara mereka adalah PULO, Barisan Revolusi Nasional Konggres (BRN-C), Bersatu, Gerakan Mujahidin Islam Pattani (GMIP), dan Barisan Pembebasan Islam Pattani. Tetapi karena pemimpin GMIP yang ditangkap di Malaysia, beberapa anggota masih melakukan operasi di Selatan, demikian juga BRN-C masih melakukan serangan. ${ }^{16}$

Di tingkat grassroot, jurnalis Muslim melakukan advokasi yang didukung oleh LSM independen di Thailand. Universitas Prince Sonkla di Pattani juga aktif mendukung upaya perdamaian. The Asian Muslim Action Network (AMAN) juga

15 Joseph Chinyong Liow, Muslim Resistence in Southern Thailand and Southern Philippines: Religion, ideology and politics, (Washington: East-West Center, 2006), 35.

${ }^{16}$ Peter Riddell, Islam And The Malay-Indonesian World, (Singapore: Horizon Book, 2001), 200. 
melakukan upaya rehabilitasi bagi masyarakat korban kekerasan dan generasi muda yang mengalami imbas negatif dari konflik. Disamping, Majelis Ugama, pondok pesantren dan madrasah secara prinsip mendukung upaya rekonsiliasi dan perdamaian. Keinginan kuat mereka tidak diimbangi dengan kebijakan pemerintah atas keamanan, dan lemahnya dukungan atas kemajuan pendidikan secara luas, dan kesempatan kerja di Selatan.

\section{b. Ekonomi}

Sampai akhir abad ke-19, kehidupan ekonomi Pattani sangat bergantung pada kegiatan ekonomi subsisten, seperti pertanian padi, penangkapan ikan, pertambangan, dan perdagangan eceran. Berbagai upaya pembaruan dan pemusatan pemerintahan yang dilakukan Raja Chulalongkorn, terutama sejak 1890-an, membuat pendatang Siam dan pedagang Cina semakin menguasai kendali ekonomi Thailand, termasuk juga Pattani.

Munculnya usaha pertambangan dan perkebunan karet yand dimodali nonmuslim sejak awal abad ke-20 ternyata tidak banyak mengubah struktur ekonomi lokal. Masyarakat muslim Pattani harus puas sebagai pekerja rendahan, seperti penyadap karet dan buruh kasar. Bahkan, peluang ekonomi yang baru muncul juga tetap meletakkan mereka pada posisi yang kurang menguntungkan dan rendah pendapatannya, seperti pesuruh di kantor-kantor dan pekerja bangunan. ${ }^{17}$

Pemerintah Thailand dan pembisnis non-muslim telah berhasil dengan baik dalam mengolah hasil bumi baik dalam bidang perkebunan maupun pertambangan, yang mana hal tersebut tidak dapat dilakukan oleh sebagian besar umat muslim. Pada akhir tahun 1970-an, lebih dari 12 pertambangan material telah dibuat, 10 diantaranya adalah penambangan terbuka di daerah selatan dan sepertiga dari pemasukan pemerintah Thailand berasal dari wilayah selatan. Meskipun demikian, apa yang dilakukan oleh pemerintah Thailand tersebut tidak mendapat respon yang baik dari sebagian masyarakat besar muslim. Karena, mereka menganggap bahwasanya pemerintahan imperialis Thailand telah merampas hasil alam masyarakat muslim Thailand. Hal ini dikarenakan tiadanya hubungan timbal balik kepada masyarakat daerah selatan. ${ }^{18}$

\section{c. Pedidikan}

Sebagian besar masyarakat muslim Thailand lebih banyak mengenal sistem pendidikan pondok pesantren, seperti yang banyak ditemukan di Jawa, sebagai institusi pendidikan bagi anak-anak mereka. Sistem pendidikan ini pertama kali diperkenalkan oleh salah seorang murid dari sunan Ampel di Jawa, yakni Wan Husein. Ia adalah salah seorang ulama yang berpengaruh di dalam pengembangan

${ }^{17}$ Taufik Abdullah, [et.al.], Ensiklopedi Tematis Dunia Islam, (Jakarta: Ichtiar Baru Van Hoeve), 466.

${ }^{18}$ Walker, Dennis P...., 86. 
Islam di Pattani. ${ }^{19}$ Hingga awal abad ke-20, di seluruh Pattani terdapat lebih 500 pondok.

Pada tahun 1921, pemerintah Thailand memberlakukan Peraturan Pendidikan Rendah. Mereka mewajibkan anak-anak muslim untuk masuk sekolah negeri Thai. Anak-anak tersebut diwajibkan menggunakan bahasa Thai, dan bahasa Melayu mulai kehilangan pemakainya. Berbagai kalangan masyarakat muslim mencurigai kebijakan "siamisasi" ini sebagai upaya pemerintah Thailand untuk menggerogoti etnis dan budaya melayu Islam. ${ }^{20}$ Hal ini, telah melahirkan protes dari sebagian besar dari masyarakat muslim Thailand. Hingga akhirnya pada tahun 1923 pemerintah mencabut segala kebijaksaannya tersebut.

Pada tahun-tahun selanjutnya, beberapa kasus ketegangan terjadi dalam hal pelaksanaan pendidikan sesuai dengan keinginan pemerintah. Hingga akhirnya, pada pertengahan tahun1960-an, beberapa perbaikan dilakukan, termasuk system pengajaran bahasa Thai, penggunaan bahasa Melayu, guru muslim, dan pemasukan silabus yang menonjolkan sejarah Islam, dan budaya Melayu. Ternyata hal-hal ini membawa kemajuan dan menarik minat kalangan muslim untuk mengikuti program sekolah formal. ${ }^{21}$

\section{Muslim Moro di Mindanao - Filipina}

Sejarah genealogi perjuangan eksistensi bangsa Moro dapat dilihat dari mulainya infiltrasi atau masuknya Islam masuk ke Filipina pada tahun $1210 \mathrm{M}$, yang bertepatan pada awal abad ke-13 M yang dibawa oleh para pedagang Arab dan para da'i> yang berasal dari Indonesia dan Malaysia. Setelah itu berdirilah kesultanan-kesultanan Islam yang mempunyai pemerintahan dan kedaulatan, di antaranya Kesultanan Sulu dan Kesultanan Mindanao. ${ }^{22}$

Muslim di Filipina terdiri atas 13 kelompok etnolinguistik, masing-masing Iranun, Magindanaon, Maranao, Tao-Sung, Sama, Yakan, Jama Mapun, Ka'agan, Kalibugan, Sangil, Molbok, Palawani, dan Badjao. Adapun muslim dari kalangan penduduk pribumi (indigenous people) di Mindanao seperti, Teduray, Manobo, Blaan, Higaonon, Subanen, T'boli dan lain-lain. Selain itu penduduk muslim juga dapat ditemui di Luzon dan Pisayas walaupun dalam sekala yang kecil. Muslim yang mendiami mindanao, Pulau Basilan, Palawan, Sulu dan Kepulauan Tawi-tawi kemudian disebut sebagai Bangsa Moro. ${ }^{23}$

${ }^{19}$ Taufil Abdullah,[et.al.], Ensiklopedi Tematis Dunia Islam,... 467.

${ }^{20}$ Taufil Abdullah, Ensiklopedi Tematis Dunia Islam...., 467

${ }^{21}$ Walker, Dennis P...., 89.

${ }^{22}$ Abu Ibrahim Muhammad Daud, The Secret of Jihad Moro: Fakta-Fakta Perlawanan Kaum Tertindas Moro (Solo: Media Islamika, 2008), 66.

${ }^{23}$ Heru Susetyo, The journal of a Muslim traveler: sebuah jurnal perjalanan melintasi Asia, Amerika, Eropa, \& Australia (Bandung: Mizan Publika, 2009), 6. 
Salah Jubair dalam bukunya yang berjudul Bangsamoro: A Nation Under Endless Tiranny (1999) menjelaskan bahwa istilah Moro atau Bangsamoro adalah istilah yang berasal dari Spanyol (Spaniards). Kata moro berasal dari bangsa Mauri atau Mauritania di Afrika yang kemudian juga dikenakan kepada Banhsa Berbers di Afrika Utara dan kepada kaum muslimin yang datang dan menaklukkan Spanyol berabad-abad silam. ${ }^{24}$ Jadi istilah moro tidaklah merujuk kepada kelompok etnis, ras, waktu dan geografis tertentu, tapi lebih merujuk kepada kelompok atau orang yang berafiliasi kepada agama tertentu seperti Islam di Mindanao, Filipina.

Kedatangan orang-orang Spanyol di Filipina pada abad-16 yang bertujuan untuk mendirikan daerah jajahan dan kristensasi terhadap orang-orang Islam, terutama pada orang-orang pribumi yang berada di Filipina. Ketika orang-orang Spanyol berhasil memasukkan orang-orang pribumi ke dalam agamanya, kaum pribumi dijadikan sekutu sebagai prajurit atau pelempar tombak dalam pertempuran, untuk menyerang perkampungan-perkampungan dan benteng-benteng Islam. Sejarah peperangan yang panjang antara orang-orang Spanyol dan Islam dinamakan Perang Moro. Akibat dari Perang Moro terjadi ketegangan dan konflik antara orang-orang Kristen dan Islam Filipina. ${ }^{25}$ Kolonial Spanyol menamakan orang Islam dengan sebutan "Moro", sedangkan orang-orang pribumi yang masuk Kristen disebut "Indio". Dari peristiwa tersebut orang Spanyol dan kaum Kristen pribumi dianggap sebagai musuh Islam yang abadi.

Konflik antara komunitas muslim Mindanao dengan komunitas etnis Visayas atau Filipino yang melakukan politik migrasi ke arah selatan. Perpindahan penduduk ini menjadi masalah yang serius tatkala sekelompok etnis Filipino dengan dibantu oleh pasukan Filipina melakukan politik genocide di awal dekade 1970-an. Sejarah konflik ini juga masih mengedepankan corak konflik etnis. Etnis Filipino maupun pemerintah Philipina memandang bahwa masyarakat Moro di Mindanao di identifikasi sebagai bangsa yang kasar, bodoh, tidak beradab dan suka melakukan tindakan kekerasan. Begitu juga bangsa masyarakat Moro juga mempunyai pandangan yang negatif terhadap kelompok Filipino dan pemerintah Philipina. Mereka mengidentifikasi kelompok tersebut sebagai kelompok penginjil yang akan mencabut keberagaman sebagaimana yang pernah dilakukan oleh rezim kolonial Spanyol. ${ }^{26}$

Pada Tahun 1898, Amerika Serikat (AS) menang dalam perang ASSpanyol. Filipina menjadi dibawah kontrol AS. Wilayah Mindanao-Sulu pada masa kolonialisasi Spanyol tidak berada dalam kontrol Spanyol, tetapi Spanyol memasukan wilayah ini dalam penyerahan kekuasaan Filipina ke AS. Akhirnya, pertempuran berdarah antara muslim Mindanao dengan penjajah AS yang berakhir

${ }^{24}$ Heru Susetyo, The journal of a Muslim traveler ..., 5.

25 Cesar A. Majul, Dinamika Islam Filipina, (Terj). Eddy Zainurry (Jakarta: LP3ES, 1989), 9-11.

26 Suwardono, Manajemen Konflik Separatisme: Dinamika Negosiasi Dalam Penyelesaian Konflik Mondanao. (Yogyakarta: Pusataka pelajar Offset, 2013), 75. 
dengan perjanjian antara sultan mindanao dengan AS yang dikenal dengan "Treaty Bates" pada 22 Agustus 1899. perjanjian ini tidak bertahan lama tiba-tiba tahun 1902, AS memasukan wilayah Mindanao ke dalam pembentukan Filipina. Pada tahun 1940, AS menghapuskan kesultanan dan kawasan Mindanao dimasukan kedalam sistem administratif Filipina. Tahun 1946, Fillipina merdeka, tapi disampaikan sebelum kemerdekaan oleh bangsa Moro kekecewaan bangsa Moro terhadap pemerintah AS disampaikan dalam memorandum Mindanao dan Sulu tidak akan mau dimasukan kedalam kemerdekaan karena pulau mereka tidak akan diberikan kepada masyarakat yang bukan bangsa kami (Moro), bahkan menurut mereka tidak pantas apabila didalam satu negara ada dua pihak yang saling bermusuhan. Akan tetapi, AS tidak menerima proposal tersebut. ${ }^{27}$

Hubungan Amerika dengan Muslim Filipina lebih baik dibandingkan dengan penjajah Spanyol, karena kebijakan Amerika memberikan kebebasan kepada orang Islam dalam menjalankan kehidupan beragama serta kebiasaankebiasaan ritualnya. Akan tetapi, Amerika membenci dan mencurigai orang Islam, karena pada dasarnya Islam datang dari luar negeri, khususnya dari Arab dan orangorang Islam bagian Selatan. Oleh sebab itu, Amerika mempersempit kontak komunikasi antara orang-orang Islam di Filipina dengan saudara-saudaranya di pulau terdekat, khususnya pulau Kalimantan atau pulau-pulau lainnya di Indonesia. $^{28}$

Akibat dari adanya sikap diskriminasi yang diterima oleh bangsa Moro sebagai kaum minoritas muslim di Filipina, maka munculah gerakan-gerakan separatis muslim di Filipina Selatan berawal dari kelompok kecil mahasiswa dan para intelektual pada tahun 1960-an. Masalah yang dihadapi oleh gerakan-gerakan separatis yaitu diskriminasi, merosotnya ekonomi (kemiskinan) dan ketidakadilan pemerintah, terutama yang berkaitan dengan pengusiran masyarakat muslim Moro dari tanah mereka sendiri oleh orang-orang Kristen. ${ }^{29}$ Oleh sebab itu, Untuk merealisasikan pemikiran Bangsa Moro untuk terbebas dari hegemoni dan dominasi dari PRF (Pemerintah Republik Filipina). Di Filipina selatan terdapat gerakangerakan separatis sebagai bentuk aktualisasi pemikiran perjuangan eksistensi minoritas Muslim Bangsa Moro, gerakan-gerakan tersebut antara lain: Moro National Liberation Front (MNLF), Moro Islamic Liberation Front (MILF) dan kelompok Abu Sayyaf.

Moro National Liberation Front/Front Pembebasan Nasional Moro (MNLF) adalah suatu gerakan perjuangan radikal yang menginginkan kemerdekaan penuh bagi Muslim Moro yang berada di Filipina Selatan. Gerakan ini didirikan

${ }^{27}$ Syed Sirajul Islam, The Politics of Islamic Identity in Southeast Asia (Singapore: Thomson Learning, 2005), 30.

${ }^{28}$ Cesar A. Majul, Dinamika Islam Filipina..., 13-15.

29 John Gershman,Peta dan Prospek Gerakan Islam di Filipina"dalam Asia Tenggara Konsentrasi Baru Kebangkitan Islam, ed. Moeflich Hasbullah, (Bandung: Fokusmedia, 2003), 238. 
oleh Nur Misuari pada tahun 1969, anggota-anggotanya dari beberapa kelompok etnis seperti etnis Tausug, Samal dan Yakan. Anggotanya terdiri dari para pemuda yang berlatar belakang dari pendidikan sekuler, pemuda tersebut mendapatkan pelatihan militer di Malaysia. Beberapa orang dari anggota MNLF pernah terlibat dalam gerakan politik mahasiswa aliran kiri.

Sebelum gerakan MNLF berdiri terdapat gerakan lain yaitu gerakan Kemerdekaan Islam/Muslim Independent Movement (MIM). Gerakan MIM ini didirikan oleh Datu Udtog Matalam pada tanggal 1 Mei 1968. Tujuan dari berdirinya gerakan MIM adalah berjuang untuk mencapai kemerdekaan bagi Mindanau dan Sulu. ${ }^{30}$ Mendorong gerakan MIM berdiri dikarenakan kondisi perekonomian menurun di kalangan masyarakat Muslim Moro dan kasus pembunuhan besar-besaran di Jubaidah. ${ }^{31}$

Gerakan yang pertama berdiri di Filipina Selatan wilayah Mindanau dan Sulu adalah gerakan MIM yakni gerakan Kemerdekaan Islam. Akan tetapi, gerakan ini dapat ditaklukkan oleh pemerintah Filipina. Kemudian terjadi kekecewaan kepada generasi-generasi muda MIM, dan pada akhirnya berdirilah gerakan MNLF yang dipelopori oleh Nur Misuari. Dia menjabat sebagai seorang lektor dan menjadi anggota staf Pusat Asia, dia lulusan dari Universitas Filipina jurusan Ilmu Politik. Pemimpin-pemimpin lain MNLF yaitu Hashim Salamat dari Cotabato dan Abdul Khair Alonto dari Lanao. Para pemimpin-pemimpin tersebut mewakili semua etnoliguistik dan kelompokkelompok daerah lainnya.

Latar belakang berdirinya gerakan MNLF (Moro National Liberation Front) yaitu pertama, terjadi perampasan tanah Muslim Moro di Mindanao oleh orang-orang Kristen yang datang ke Mindanao, karena adanya perpindahan penduduk orang-orang Kristen dari Utara ke Selatan orang-orang Islam di Mindanao, peristiwa tersebut atas perintah pemerintahan Filipina. Akibatnya Filipina Selatan khususnya Mindanao dan Sulu menjadi Minoritas, yang asal mulanya dilihat dari segi historis dulu Filipina Selatan adalah mayoritas. Kedua, terjadi peristiwa pembunuhan besar-besaran di Jabidah yang dikenal dengan nama Insiden Corregidor pada bulan Maret 1968 di pulau Corrogidor.

Pandangan gerakan radikal MNLF yaitu pandangan yang ingin memprakarsai berbagai perubahan dalam masyarakat yang lebih luas, Kebangkitan Islam sering dikaitkan dengan suatu penafsiran yang militan. Seperti hal dalam manifesto MNLF yakni menyerukan pentingnya menegakkan "Bangsa Moro". ${ }^{32}$ Manifesto atau pernyataan dari pembentukan Bangsa Moro yang bertujuan untuk membebaskan diri dari teror dan penindasan penguasa kolonialisme Filipina,

${ }^{30}$ Cesar A. Majul, Dinamika Islam Filipina ..., 43.

${ }^{31}$ Asy'ari dkk, Pengantar Studi Islam (Surabaya: IAIN Sunan Ampel Press, 2008),

309.

${ }^{32}$ Taufik Abdullah dan Sharon Siddique, Tradisi dan Kebangkitan Islam di Asia Tenggara.,terj. Rochman Achwan, (Jakarta: LP3ES, 1988), 347. 
mereka memperoleh kemerdekaan pada tanggal 18 Maret 1974 di tanah air mereka yang dipelopori oleh Nur Misuari yang sebagai Ketua Komite Sentral Front Pembebasan Nasional Moro. ${ }^{33}$

\section{Penyelesaian Konflik Mindanao}

Konflik yang berlarut-larut di Mindanao Filipina selatan bukan tanpa adanyanya usaha dari berbagai pihak untuk mengakhiri konflik ini. Baik yang dipelopori dari dalam maupun campurtangan pihak asing.

Pada tahun 1976, pemerintah Filipina dan pimpinan MNLF melakukan perjanjian yang dikenal dengan perjanjian Tripoli melalui mediasi Organisasi Konferensi Islam (OKI), perjanjian ini dipimpin oleh Libya. ${ }^{34}$ Perjanjian tersebut menghasilkan beberapa poin yaitu hak otonomi daerah untuk 13 provinsi di Mindanao, Sulu dan kepulauan Palawan sebagai wilayah yang paling berpengaruh terhadap MNLF. Otonomi penuh diberikan pada bidang pendidikan dan pengadilan sementara bidang pertahanan dan politik luarnegeri tetap berada dibawah kebijakan pemerintah Filipina. ${ }^{35}$ Perjanjian tersebut tidak ditaati karena banyaknya penafsiran sehingga tidak bisa diimplementasikan. Gagalnya perjanjian Tripoli menyebabkan MNLF kembali menyerang militer Filipina. Saat itu juga terjadi peristiwa besar dimana MNLF terpisah menjadi 2 bagian yaitu Moro Islamic Liberation Front (MILF) dipimpin oleh Salamat Hashim dan MNLF dipimpin oleh Dimas Pundatu. ${ }^{36}$

Tahun 1986 presiden Marcos digantikan oleh presiden Cory Aquino. Aquino melakukan pertemuan dengan Nur Misuari dan MNLF di Sulu. Pertemuan ini menimbulkan kemarahan pimpinan MILF karena pemerintah Filipina tidak mengajak perwakilan dari MILF juga. Langkah tersebut sebagai jalan pembuka untuk melakukan negosiasi. Sayangnya, ini membutuhkan waktu 10 tahun untuk mencapai kesepakatan.

Pada 2 september 1996 dibawah pimpinan Fidel V.Ramos telah ditandangani perjanjian "Final Peace Agreement" (FPA). Perjanjian tersebut telah berhasil mengawali terbentuknya proses rekonsiliasi terhadap MNLF saja tidak termasuk komunitas MILF. Akan tetapi hal ini hanya membawa keuntungan bagi MNLF sebagai pihak yang melakukan perjanjian, adapun MILF menjadi sebuah

${ }^{33}$ Dikutip dari Mahardika,Vol. IX, No. 1, 1982. Dalam bukunya Cesar A. Majul, Dinamika Islam Filipina, lampiran II, 155-156.

${ }^{34}$ Dinamakan persetujuan Tripoli karena negosiasi berlangsung di Tripoli, Libya. Berdasarkan perbincangan Imelda Marcos dengan Qoddafi, perjanjian ini juga berkat bantuan Organisasi Konferensi Islam (OKI)

35 John L. Esposito. Islam in Asia Religion, Politics and Society (New York: Oxford University Press, 1987), 107.

${ }^{36}$ Rufa Cagoco-Guiam. Mindanao: Conflicting Agendas, Stumbling Blocks and Prospects Towards Sustainable Peace. Dalam buku Searching for Peace in Asia Pacific: an Overview of Conflict prevention and peace building activities, (United States: Lynne Rienner Publisher,inc. 2004), 487. 
tantangan baru bagi pemerintah Filipina. ${ }^{37}$ Pada masa pemerintahan presiden Estrada terjadi pembombardiran tentara Filipina AFP terhadap MILF. Aksi All out War berhasil menghancurkan kamp Abu Bakar merupakan salah satu kamp terbesar MILF yang dikelilingi komunitas pemukiman Muslim. Dengan demikian masalah ini malahan menjadikan penginternasionalisasian konflik antara pemerintah Filipina dengan MILF, sehingga menjadikan awal bagi MILF untuk membangun perjuangan secara diplomatik dalam forum internasional terutama di OKI. ${ }^{38}$

\section{a. Negosiasi dalam Tripoli Agreement 1976}

Upaya peneyelesaian konflik ini diprakarsai oleh OKI pada tahun 1973 dengan membentuk komisi 4 negara. Ke 4 anggotanya adalah Libia, Arab Saudi, Senegal dan Somalia untuk menyelidiki kasus kasus kekerasan yang dilakukan pemerintah Filipina terhadap Moro.namun bertambah menjadi 6 negara setelah Indonesia dan Bangladesh sebagai anggotanya.

Hasil dari Tripoli Agreement adalah diakuinya secarah sah wilayah otonomi Mindanao yang meliputi 13 daerah seperti daerah Basilan, Sulu, TawiTawi, Zamboangan del zur, Zamboangan del Norte, Lanao del Sur, Davao del Sur, South Cotabato, Palawan, serta semua kota dan desa diwilayah tersebut. Dalam perjanjian ini juga mengatur kawasan Otonom untuk mendirikan pengadilan syari'ah, sekolah, system administrasi, system ekonomi dan keuangan, keamanan kawasan, badan perwakilan dan dewan eksekutif. Hal - hal mengenai kebijakan politik Luar Negeri dan Pertahanan nasional tetap menjadi tanggung jawab pemerintahan Pusat. Dan membuat wadah yang mernaman pemerintahan otonomi Moro (ARMM)

\section{b. Negosiasi Jeddah Accord 1987}

Menjelang tahun 90an kekuasan pemerintahan pusat Filipina terganggu, hal ini membuat faksi-faksi muslim Moro kembali melakukan mobilisasi kekuatan untuk memanfaatkan moment tersebut untuk mendeklarasikan pembentukan Negara Moro Merdeka. MNLF yang selama menjalankan Tripoli Agreement merasa dikapitulasi oleh kebijakan marcos memilih untuk melanjutkan perjuangan bersenjata untuk pembentukan Negara yang merdeka.

Dalam menghadapi mobilisasi di Minandao presidan Aquino meminta negosiasi dilakukan lagi, akhirnya disetujui oleh Nur Misuari pemimpin MNLF. Akhirnya 3 orang dikirim ke Jeddah, Arab Saudi guna bernegosiasi. Aquino bersedia berunding masalah ekonomi, politik, social dan budaya kecuali perbincangan tentang isu Moro Merdeka. Hasil dari negosiasi antara MNLF dan

${ }^{37}$ Rufa Cagoco-Guiam. Mindanao: Conflicting Agendas ..., 487.

${ }^{38}$ Erni Budiwanti. Tantangan Pembangunan Negara Bangsa di Filipina: Gerakan Separatisme Moro. Pusat Penelitian Sumber Daya Regional (PSDR-LIPI) didalam katalog.pdii.lipi.go.id 
Pemerintah Filipina adalah peningkatan status dari sebelumnya wilayah otonom menjadi wilayah Otonomi diperluas.

\section{c. Range Negosiasi Final Peace Agreement 1966}

Proses perdamaian di Mindanau selatan terus berlangasung setelah bergantinya rezim Presiden Aquino dengan Fidel Ramos yang lebih proaktif. Seiring berjalannya waktu kelompok kelompok miitan seperti Abbu Sayaf terus melakukan terror dan serangan-serangan di Mindanao, termasuk melakukan penculikan dengan tebusan. Meskipun kekerasan terus berlangsung Presiden Ramos tetap akan melanjutkan usaha perdamaian di Mindanao selatan.

Pada tanggal 2 September 1996, Final Peace Agreement disepakati secara formal dengan disaksikan oleh menteri luar negeri Indonesia, Ali Alatas dan Sekjen OKI di Jakarta. Dengan menghasilkan 81 Point kesepakatan yang intinya adalah meningkatkan status wilayah otonomi diperluas menjadi ekonomi khusus. Melaksanakan pemilihan umum untuk daerah Mindanao dan dimenangkan oleh Nur Misuari dengan $90 \%$ suara. $^{39}$

\section{B. Penutup}

Pertikaian yang terjadi terus-menerus antara masyarakat muslim dengan pemerintah Thailand lebih cenderung dipengaruhi oleh faktor ideologi, sosial, ras dan budaya. Kebijakan-kebijakan yang diberlakukan oleh pemerintah cenderung mendiskriminasi masyarakat muslim. Hal ini telah menyebabkan sebagaian dari masyarakat muslim tersebut ikut bergabung dengan gerakan antipemerintah, bahkan gerakan ini cenderung kepada aksi kekerasan. Usaha pemerintah dalam menangani konflik ini tidak akan berhasil tanpa adanya rekonsiliasi antara pemerintah dan masyarakat muslim dan persamaan dalam ide, gagasan dan pedapat.

Wilayah Thailand bagian selatan sudah mengalami ketegangan sejak awal tahun 1990-an. Ketegangan yang terjadi adalah antara etnis Muslim-Melayu yang menjadi warga mayoritas kawasan Thailand Selatan dengan Pemerintah Thailand. Hal ini terjadi karena ketidakpuasan etnis Muslim-Melayu terhadap kebijakan dikeluarkan Pemerintah Thailand yang dianggap tidak memihak mereka dan diskriminatif. Masalah yang berlangsung lama dan berlarut di wilayah Thailand Selatan ini memaksa etnis Muslim-Melayu untuk melakukan sejumlah pemberontakan.

Pemberontakan yang dilakukan kelompok etnonasionalisme Muslim Melayu dikendalikan dan diorganisir oleh sejumlah organisasi di belakangnya. Organisasi tersebut seperti BRN - C, PULO, serta GMIP. Ketiga organisasi ini merupakan organisasi yang menginginkan adanya perubahan akan nasib etnis Muslim-Melayu di Thailand.

\footnotetext{
${ }^{39}$ Suwardono, Manajemen Konflik Separatisme ..., 127-147.
} 
Konflik Moro di Minandao Filipina selatan merupakan konflik berkepanjangan yang belum terselesaikan. Usaha-usaha yang dilakukan untuk proses perdamaian terus dilakukan beriringan dengan usaha-usaha kemerdekaan yag terus dikumandangkan oleh para kelompok separatis-separatis moro untuk membentuk sebuah Negara sendiri yang merdeka dan bebas dari Intervensi pemerintahan Filipina. Isu-isu agama yang diawa dalam konflik ini membuat konflik ini semakin memanas. Konflik ini akan terus berlanjut apabila kamu minoritas muslim difilipina terus mendapat tekanan-tekanan politik dari pemerintahan pusat. Satu kata yang mereka tuntut hanyalah merdeka.

Konflik dan Kemiskinan dua hal yang tidak pernah bisa kita pisahkan. Konflik yang berlarut-larut menimbulkan berbagai dampak baik dalam hal ekonomi dan pendidikan. Konflik yang terjadi menciptakan suatu kondisi dimana tingkat keamanan sangat rendah, hal ini memengaruhi sistim ekonomi Moro yang mengalami gangguan khususnya dalam Hal Investasi yang rendah. Banyak anakanak moro yang tidak bias bersekolah akibat sekolahnya digunakan sebagai temppat pengungsian. Infrastruktur rusak dan rumah-rumah harus ditinggalkan akibat konflikini. Biaya pembangunan kembali Minandao paska konflik membutuhkan jumlah biaya pembangunan yang tidak sedikit. 


\section{Daftar Pustaka}

Abdullah, Taufik dan Sharon Siddique, Tradisi dan Kebangkitan Islam di Asia Tenggara.,terj. Rochman Achwan. Jakarta: LP3ES, 1988.

Abdullah, Taufik. [et.al.], Ensiklopedi Tematis Dunia Islam. Jakarta: Ichtiar Baru Van Hoeve.

Aphornsuvan, Thanet. History and Politics of The Muslim in Thailand. Thammasat University: 2003.

Aslam, Moh Mizan. Penyelesaian Konflik Thailand Selatan Menggunakan Model Gagasan Gagasan 1 Malaisya, Journal of Human Development and Comunications, Vol. 12012.

As-Sirjani, Ragib. The Harmony of Humanity (trj). Jakarta: Pustaka Al-Kautsar, 2015.

Asy’ari dkk, Pengantar Studi Islam. Surabaya: IAIN Sunan Ampel Press, 2008.

Azra, Azyumardi. Ensiklopedi Tematis Dunia Islam, Asia Tenggara, No. 5. Jakarta: PT Ichtiar Baru Van Hoeve, 2002.

Azra, Azyumardi. Kebangkitan Islam Akan Muncul Dari Melayu, dalam buku Asia Tenggara Konsentrasi Baru Kebangkitan Islam, editor: Moeflich Hasbullah. Bandung: Fokusmedia, 2003.

Brown, David. The State and Ethnic Politics in South-East Asia. London dan New York: Routledge, 2004.

Budiwanti, Erni. Tantangan Pembangunan Negara Bangsa di Filipina: Gerakan Separatisme Moro. Pusat Penelitian Sumber Daya Regional (PSDR-LIPI) didalam katalog.pdii.lipi.go.id

Daud, Abu Ibrahim Muhammad. The Secret of Jihad Moro: Fakta-Fakta Perlawanan Kaum Tertindas Moro. Solo: Media Islamika, 2008.

Esposito. John L. Islam in Asia Religion, Politics and Society. New York: Oxford University Press, 1987.

Gershman, John. Peta dan Prospek Gerakan Islam di Filipina"dalam Asia Tenggara Konsentrasi Baru Kebangkitan Islam, ed. Moeflich Hasbullah. Bandung: Fokusmedia, 2003.

Guiam, Rufa Cagoco. Mindanao: Conflicting Agendas, Stumbling Blocks and Prospects Towards Sustainable Peace. Dalam buku Searching for Peace in Asia Pacific: an Overview of Conflict prevention and peace building activities. United States: Lynne Rienner Publisher,inc. 2004.

Islam, Syed Sirajul. The Politics of Islamic Identity in Southeast Asia. Singapore: Thomson Learning, 2005.

Joseph Chinyong, Liow. Muslim Resistence in Southern Thailand and Southern Philippines: Religion, ideology and politics. Washington: East-West Center, 2006.

Kettani, Houssain. International Journal of Environmental Science and Development, Vol. 1, No. 2, June 2010. 
Kettani, M.Ali. Minoritas Muslim di Dunia Dewasa Ini, (terj.) Zarkowie Soejoeti. Jakarta: PT. RajaGrafindo Persada, 2005.

Khan, Ayub. "Wanita Dan Terorisme: Analisis Wacana Kritis (CDA) Terhadap "Woman And Teror" Dalam Laporan Majalah Newsweek 12 Desember 2005". Penelitian Research Grant Phk A-2 2006.

Lintner, Bertil. Burma in Revolt:Opium and insurgency since 1948. Wesiview Press, California, 1994.

Liow, Joseph Chinyong. Muslim Resistence in Southern Thailand and Southern Philippines: Religion, ideology and politics. Washington: East-West Center, 2006.

Mahardika,Vol. IX, No. 1, 1982. Dalam bukunya Cesar A. Majul, Dinamika Islam Filipina, lampiran II.

Majul, Cesar A. Dinamika Islam Filipina, (Terj). Eddy Zainurry. Jakarta: LP3ES, 1989.

Maryam, Siti. Sejarah Peradaban Islam Dari Masa Klasik Hingga Modern. Yogyakarta: Lesfi, 2004.

Mubasirun. "Persoalan Dilematis Muslim Minoritas Dan Solusinya". Epistemé, Vol. 10, No. 1, Juni 2015.

Mujani, Saiful. (edt), Pembangunan dan Kebangkitan Islam di Asia Tenggara. Jakarta: LP3ES, 1993.

Munjin. "Muslim Minoritas Dan Wacana Gender Di Australia". Jurnal Studi Gender \& Anak, Vol.4 No.1 Jan-Jun 2009 Pp.140-157.

Peter, Riddell. Islam And The Malay-Indonesian World. Singapore: Horizon Book, 2001.

Pitsuwan, Surin. Islam di Muangthai Nasionalisme Melayu Masyarakat Patan. Jakarta: LP3ES, 1989.

Rehayati, Rina. "Minoritas Muslim: Belajar dari Kasus Minoritas Muslim di Filipina”. Jurnal Ushuluddin Vol. XVII No. 2, Juli 2011.

Rose, M. Arnold and B. Carroline Rose. Minoritas Problems. New York: Herper and Row, 1972.

Suaedy, Ahmad dkk. Islam Dan Kaum Minoritas: Tantangan Kontemporer. Jakarta: The Wahid Institute, 2012.

Susetyo, Heru. The journal of a Muslim traveler: sebuah jurnal perjalanan melintasi Asia, Amerika, Eropa, \& Australia. Bandung: Mizan Publika, 2009.

Suwardono, Manajemen Konflik Separatisme: Dinamika Negosiasi Dalam Penyelesaian Konflik Mondanao. Yogyakarta: Pusataka pelajar Offset, 2013.

Yuniarto, Paulus Rudolf . "Minoritas Muslim Thailand Asimilasi, Perlawanan Budaya Dan Akar Gerakan Separatisme". Jurnal Masyarakat Dan Budaya, Volume 7 No.1 Tahun 2005. 